\title{
BLACK IS NOT AS BEAUTIFUL: GENDER, SEXUALITY AND TOURISM IN PANAMA
}

\author{
Autora: GUERRÓN MONTERO, CARLA \\ Associate Professor Department of Anthropology \\ cguerron@udel.edu.
}

\begin{abstract}
In spite of its centrality, the 'body' has remained surprisingly sparse from the corpus of tourism studies in the social sciences. Recent work has focused on the tourist gaze as gendered, sexualized and ethnicized, exposing the often implicit masculine possessor of this gaze. This article studies the host's gaze as produced partly as a result of returning the tourist gaze. I argue that Afro-Antillean men and women in the Archipelago of Bocas del Toro (Panama) produce embodied gazes that result from historical constructs as well as from returning the gazes of those of the recent constant wave of tourists landing on their shores.
\end{abstract}

I discuss how male and female bodies are conceptualized in the Archipelago as repositories of moral values; how gender, race, and class intersect in the production of these conceptualizations; and how these interpretations connect in harmonious and conflicting ways with tourism development in the region.

\section{Key words}

Gender, sexuality, tourism, Afro-Antillean/West Indian, Panama.

\section{Introduction: The body in tourism studies}

Tourism, understood as the sum of phenomena and relationships arising from the interaction of tourists, business suppliers, host governments, and host communities in the course of attracting and hosting tourists (McIntosh et al., 1999: 10), is a fine example of the consumption process. Consumption in tourism has been described as having intimate connections with sexual desire and scopophillia (Mackie, 2000). Pritchard and Morgan (2005) point out that "discourses of sexuality and sensuality frequently frame the marketing of contemporary destinations, hotels and tourist resorts, often implying the promise of risk, novelty and excitement, sometimes in exoticized and occasionally eroticized language" (2005: 286). And yet, while there has been research discussing the role of 'hosts' as sexualized beings in tourism marketing literature (Pritchard, 2001), and on how 'tourist' bodies are seen materially and symbolically in popular cultural forms (Jordan and Fleming, 2005; Pritchard and Morgan, 2005), the body has remained surprisingly sparse from the corpus of studies on tourism in the social sciences (but see Veijola and Jokinen, 1994; Jokinen and Veijola, 1997; Johnston, 2001). Pritchard and Morgan state,

\begin{abstract}
It is fair to say that few tourism studies focus on the body per se and [. . .] just as they are in everyday life, bodies have been taken for granted in tourism studies - despite their primacy in how we encounter, interact and communicate with the social and physical world (Pritchard and Morgan, 2005: 286).
\end{abstract}

The influential work by Soile Veijola and Eeva Jokinen (1994), "The Body in Tourism", initiated the interest of social science scholars on the embodied politics of travel and sexuality, areas ostensibly neglected in part due to an overpowering emphasis on the "tourist gaze" (Urry, 1990) (rather than on the tourist's and host's bodies). Recent studies have focused on the tourist gaze as gendered, sexualized and 
ethnicized, exposing the often implicit masculine possessor of this gaze (e.g. Rose, 1993; Dubinsky, 1994; Morgan and Pritchard, 1998). This article concentrates on the study of the host's gaze as gendered, sexed, and ethnicized and as produced partly as a result of returning the tourist gaze. The centrality of the host's gaze - Gillespie (2006) calls it the "reverse gaze" referring specifically to the relationship between the photographer and the photographed - has been less developed in tourism literature, and mostly centered on how this reverse gaze transforms the tourist (2006: 347). In this piece, I argue that Afro-Antillean men and women in the Archipelago of Bocas del Toro (Panama) produce embodied gazes that result from historical constructs as well as from returning the gazes of those of the recent constant wave of tourists landing on their shores ${ }^{1}$. The encounter between (mostly western) tourists and Afro-Antillean hosts in Panama cannot be understood without stressing the colonial and postcolonial history of this group, which has rendered them simultaneously cosmopolitan and provincial. My own ethnographic gaze is directed at understanding how Afro-Antilleans accommodate innovatively to the ways in which western tourists understand, approach, and expect Afro-Antilleans to behave and be, among themselves as well as among tourists.

Tourism studies have focused indirectly on the body by studying women's central role in the service sector of tourism, a "hospitality" industry (Sinclair, 1997; Kinnaird and Hall, 1994; Swain 1995) and by looking at how women perform the majority of this "serviceoriented" labor. In addition, sex has always been a part of tourism and the ritual conventions of the beach. Arguably, the bodies on display at the beach also entice a sexualized subjectivity, "while the media and cultural forces of globalization generate a wealth of material suggesting that sensual pleasures and the fulfillment of bodily desires are part of the tourism experience" (Pritchard and Morgan, 2005: 286). Tourism destinations become locations where moral ambiguity and even promiscuity are not only accepted but encouraged. As is well known, certain destinations profit precisely from the presumed moral reversals advertised in these locations (Opperman, 1998; Sánchez Taylor, 2001; Brennan, 2004), while in others tourism mediators and hosts work diligently towards eliminating these views. Gordon (2006) has noted that, regardless of whether they actually materialize, moral indulgences often figure significantly in the tales and fantasies of both hosts and guests. "Whether or not travelers actually engage in sex while abroad, sexual encounters often feature prominently in tales and fantasies, not only of the adventurers, but also of the local people on the site of the adventure" (Gordon, 2006: 8).

Tourism is a dominant industry in the third world. Tourism is perhaps one of the few industries where certain specific racialized groups, both men and women, become both tourist attractions and sexualized objects for tourism consumption, producing a reversal of the ways in which development paradigms applied in the third world strip women of their sexuality while overly imbuing gay men with themes of sexual desire and pleasure (Paulson, 2007) ${ }^{2}$. In the Archipelago of Bocas del Toro, gender and sex ideologies change and continue to "inform peoples' self-image, performance, and life choices" (Brennan, 2004: 708; O' Connell Davidson, 1998, 2002). In this article, I discuss how the male and female bodies are conceptualized in the Archipelago as repositories of moral values; how gender, race, and class intersect in the production of these conceptualizations; and how these interpretations connect in harmonious and conflicting ways with the relatively recent tourism development in the region ${ }^{3}$.

\footnotetext{
${ }^{1}$ As I use the term in this article, gender relations refer to the interpersonal relations between men and men, as well as to the economic or political relations between women and the state, and between men and the state. These relations intersect with other oppressive relations, including those that arise from race, class, ethnicity, age or sexual preference (Barriteau 1998:190). Gendered identities are "multiple and mutable, sub-culturally specific and historically variable. They are also mutually influential and overlapping, even interchangeable" (Barrow 1998: xx).
}

\footnotetext{
${ }^{2}$ Jolly (2000: 81) asks, "How can we address sexuality in Latin America without imposing Western concepts and agendas? How can we go beyond the assumption (particularly within development agendas) that while people in the global North need sex and love, people in the global South just need to eat?" ${ }^{3}$ I do not address sex tourism in this article, for it has not been the focus of my ethnographic gaze. In addition, even though sex tourism does exist in Bocas, the Archipelago is not a "sexcape" as is the case with other Caribbean destinations (Brennan 2004).
} 


\section{The tourism industry in Panama}

Since the 1990s, Panamanian administrations have turned their gaze to the tourism industry as a major revenue source for the Isthmus ${ }^{4}$. In the quest to enhance economic development in the country, the government of Guillermo Endara (1989-1994) declared tourism a national priority (IPAT, 1993: i), and in an effort to develop new destinations, Endara signed an agreement with the Organization of American States (OAS) to develop a tourism plan for the country. The result of this agreement was the creation of the Tourism Development Master Plan (TDMP) known simply as the "Master Plan." The plan was a framework for the industry's future growth (Anicetti, 1998: 70), and it was meant to become a guiding document for the Panamanian tourism industry, and to be fully implemented by the year 2002. The Master Plan divided Panama into ten tourism sections or zones. The Archipelago of Bocas del Toro, where a large number of Panamanian Afro-Antilleans live, was identified as Zone No. 2 (Bastimentos).

Currently, the Archipelago of Bocas del Toro is one of the most visited tourism areas in the country by national and international tourists. Tourism has become a permanent fixture in the region. The Instituto Panameño de Turismo, (Panamanian Bureau of Tourism, or IPAT) markets the islands as the finest example of ecotourism, although more recently, 'residential tourism' has become the business of choice. National parks and reserves, pristine beaches, water sports, rare flora and fauna, and traditional Caribbean architecture are highlighted as major attractions of the islands. Although less prominently, a Caribbean "flair" and "carefree lifestyle" (represented by AfroAntillean culture) are also advertised.

The Archipelago has approximately 18,000 inhabitants distributed across nine inhabited islands. It represents a microcosm of the multicultural elements found in Panama, including Afro-Antilleans, Chinese, indigenous groups (particularly Ngöbe and some $\mathrm{Ku}-$ na), Panamanian Latinos (the term used in Panama to refer to mestizos), and resident expatriates, mostly

\footnotetext{
${ }^{4}$ Prior to this period of intensive and deliberate tourism development by the Panamanian government, the tourism industry was present at low scale and was focused on the Panama Canal, the Colon Duty Free Zone, and the Archipelago of San Blas (Kuna Yala). The Panamanian Bureau of Tourism was created in the 1960s.
}

from Europe and North America. Afro-Antilleans in Bocas del Toro are descendants of black slaves from the British West Indies and more recent waves of migration. The first Afro-Antillean settlers arrived in Bocas in the early 1800 s as slave workers for Irish, English and Scottish families who migrated to the area from the West Indies, particularly from Jamaica and Barbados. There were subsequent voluntary migrations of Afro-Antilleans to plantations. Most AfroAntilleans in the Archipelago speak Creole English in addition to Spanish (Guerrón Montero, 2002: 116, 140-145). From the nineteenth to the late twentieth century, Afro-Antilleans in the Archipelago worked mainly for the United Fruit Company, in agriculture and fishing activities for self-subsistence, and in bureaucratic service jobs. This structure changed considerably with the development of tourism in the Archipelago in the mid-1990s.

The development of the tourism industry in Panama provided an unexpected windfall of political and cultural capital for the Archipelago and for AfroAntilleans. The TDMP recognized the touristic opportunities of Bocas by classifying its territory as part of Zone 2, Bastimentos (ITCA, 1993: 40). Bocas is now one of the main points of touristic development in Panama. In 1990, there were only three hotels and four restaurants in the Archipelago. By September 2000, there were 30 hotels, hostels, and boarding houses, 28 restaurants, 2 travel agencies, 9 tour operators, 3 flight lines, 26 taxis, 6 vans, and 7 businesses devoted to renting bicycles, motorcycles, kayaks and scuba diving equipment; and these numbers are growing. Most of the tourism facilities available in Bocas are low- and medium-priced hotels and restaurants, frequently owned by foreigners. There is very little government investment in the industry.

Bocas is portrayed as a prime example of ecotourism in the Caribbean, and it is nowadays considered, in Panama as well as abroad, the fashionable place to be, a "hot commodity" that everyone wants to enjoy and own. Bocas has been the setting for a considerable number of documentaries, reports, and articles in the national and international media since 1995. In addition to ecotourism, religious tourism and ethnic tourism have been promoted ${ }^{5}$. 


\section{Gender roles and tourism}

Crain (1996) states, "touristic consumption frequently relies on gender differences, on culturally constructed notions of 'femininity' and 'masculinity,' in order to establish meanings, that make the touristic experience appealing to diverse audiences" (1996: 125). These constructed notions occur in opposition and thus in relationship to each other. The dynamics of gender in a given society take place through the ongoing negotiations between men and women individually as well as collectively (Mohammed, 1998: 8). Gender roles are clearly differentiated in Bocas del Toro. Men work outside the home, particularly in agriculture, as fishermen, construction workers, and bureaucrats or on tourism-related activities. Some men are experienced cooks; however, the everyday tasks of cooking and other household chores are the responsibility of women. A worthy woman is one who is able to take care of her household and family at all times. Women's labors need to be understood "within the broader context of their roles as mothers, as "the centrality of motherhood is and remains a focal aspect of self-identity for children in the community" (Johnson Osirim, 1997: 43). Women are also praised for their entrepreneurial abilities. It is very common for women to be involved in domino or card clubs (in which men also participate), susús (informal savings cooperatives), committees to gather funds for their children's schools, and even transnational companies such as Avon and Amway. Girls are trained at a young age to learn the importance of economic means, and are praised and encouraged if they demonstrate interest in financial issues, or a special ability to collect debts.

In a society where people are highly aware of each other's fortunes and misfortunes, keeping a positive public image at all times is extremely important. This concern with personal appearance and household cleanliness is also replicated in the attention that women maids, cooks, or managers give to their hosts in

\footnotetext{
${ }^{5}$ In Bocas del Toro, ecotourism refers to touristic activities centered on exploring the flora and fauna of the islands. Religious tourism refers to organized group visits to specific religious events organized by the Catholic and Protestant Churches. Ethnic tourism refers to visits to the largest indigenous group in the country, the Ngöbe, who inhabit some of the islands in the Archipelago (Bastimentos, San Cristobal, Isla Popa, and Solarte, among others).
}

hotels, hostels, boarding houses or restaurants. Women "conquer" and maintain their partners, or even attract other women's partners, by focusing on the man's food and personal appearance, and overall household tasks.

Afro-Antillean participation in tourism is also gendered. Men mostly work as tour guides, boat and taxi drivers, and construction workers. In addition, there are some who work as cooks, and who are renowned for their cooking abilities. Men also participate in the entertainment industry, owning, managing, or working in restaurants and bars. Women who work in tourism do so as maids and cooks. A few women also work as tour guides and taxi drivers, and a handful as boat drivers. Several women have opened small restaurants, or they cook some dishes in the afternoon for tourists and locals and sell them from their homes.

Historically Afro-Antillean men and women have left their home countries in the Antilles to move to Panama in search of upward mobility. While in Panama, many moved to Bocas del Toro to work on the banana plantations; some migrated to other countries of Central and South America and to the United States and Europe. Once in Bocas del Toro, AfroAntillean men established themselves in the towns of Bocas Town (Colon Island) and Bastimentos (Bastimentos Islands), and later in the mainland towns of Almirante and Changuinola, in search of income. With the onset of tourism in the Archipelago, AfroAntillean men have access to job opportunities in their own town, and there is now less need to migrate. At the same time, their work in tourism-related activities also implies constant mobilization, particularly if they work as tourist guides or boat drivers. In addition, many men still choose to work as crew members on cruise ships for months at a time, returning home twice a year for a few weeks at a time ${ }^{6}$. Afro-Antillean women have tended to search for job opportunities at home. However, it is not uncommon that women study to become teachers, nurses, or nurse aids for the public system, and if they are assigned positions outside Bocas Town, they accept those job opportunities.

\footnotetext{
${ }^{6}$ This migration pattern is also common in other parts of the Atlantic coast of Central America.
} 
Many teachers, nurses, and nurse aids stay where they work during the week and spend the weekends at home with their family; others make two-hour daily trips to their place of work, and return in the afternoon to attend to their families. Many of the women who live in their place of work are married and have children. Normally, grandparents or fathers take care of the children. Because this is indeed a common arrangement, it does not threaten the masculinity of the male, and many support their partners or wives by paying for their education and by looking after the children while the women are away. For some men, this is the ideal arrangement for it gives them the opportunity to engage in extramarital affairs.

With the onset of tourism, the steady presence of white women (and, more recently, white men) traveling or settling alone has generated transformations and new dynamics in personal relations and understandings of the body. There is a strong attraction toward whiteness in Bocas del Toro. The fascination includes the hope of maintaining transient adventures with Anglo-Saxons, but in some circumstances, the interest is in bearing mixed children. This attraction is assumed to be stronger than a person's will, particularly in the case of men. According to Bryan Ramirez, a black man who works at the Bocas airport, "we now have access to white women. Our desire for them is so strong that if they sent us an army of white women [referring to the 1989 US invasion of Panama] there would be divorces all over the place" (interview B. R., October 23, 1999). For some Afro-Antilleans the presence of Anglo-Saxon men and women has the potential to negatively affect the population. An Afro-Antillean elder feared no one will be interested in black women in the future, since his friends had commented: "If I were 20 years younger, I would be trying to attract one of those white tourists."

Consequently, it is relatively frequently that men leave their families and steady relationships in pursuit of a relationship with a white woman. Although Afro-Antillean men are willing to interact with Anglo-Saxon men and women, Afro-Antillean women are not as prone to relate to white female tourists or resident expatriates. A white couple or a white family are perceived as safer and more stable. According to a white female resident expatriate who owned a bed and breakfast,
Certainly, men are by far the easiest people to get to know, because I've had a problem making friends with the women. The men are always out there; they are working, they are on the boats, or talking to you on the streets. I know so many men because they are electricians or plumbers. The women are more in the homes or doing other things, so it's the men that have the relationships with the tourists (interview T. W., January 18, 2005).

The reasons for this apparently uncontrollable attraction vary. When I asked about the motivations for this attraction, the majority of men simply answered: "White flesh is the ruin of Black men." This statement encompasses the ideal standards of beauty and racial ascription of Bocatoreneans, who utilize physical appearance, skin color and facial features as means to determine individuals' racial and ethnic identity. Bocatoreneans are aware that hybridization has been so intense in this region ${ }^{7}$, that, as one black person said, "everyone in Bocas is a Zulú", (meaning "everyone in Bocas has some degree of Black ancestry") and thus no one could deny their black, Indian (be it Ngöbe, Teribe, or even from other Central American ancestors, such as Miskitu Indians), Latino or mixed ancestry. In spite of these affirmations, people's skin color and hair texture are extremely important for daily definitions of beauty and identity. Bocatoreneans make distinctions based on skin color and hair texture. These two elements determine whether a person is called a culisa (a mixture of black and Indian, mostly applied to women with brown skin and straight hair), a chombo blanco (a person with light skin color and extremely curly, "kinky" hair), a Pania (a white or Latino person who speaks Spanish and has light features and straight hair), or a white man or woman from the United States or Europe (a gringo/a). As Wiltshire-Brodber notes,

\footnotetext{
${ }^{7}$ When I use the notion of hybridization in this research, I am not simply replacing the word "miscegenation" or Mestizaje for a more fashionable word. I understand hybridization - as it relates to Afro-Antilleans - as "the source of structural or systemic ambivalences because it enmeshes the anticolonial thinker in imperial meanings and values that operate below his or her awareness and volition" (Henry 2000: 49). In accordance with García Canclini's (1992) work, I believe that the term hybridization encompasses diverse intercultural mixtures, more than only racial (mestizaje) or religious (syncretism) mixtures (1992: 15).

${ }^{8}$ A related phrase in nations such as Peru and Ecuador: "El que no tiene de Inga [Inca], tiene de Mandinga," meaning that every Peruvian or Ecuadorian invariably has some degree of indigenous or Black ancestry.
} 
Standards of beauty still rest heavily on how closely one approximates to the European ideal, thus reinforcing a racial dimension to the issue of gender and status [. . .] Race, class and colour thus cut squarely across gender, depriving the issue of gender relations in them of any force for radicalism and change (Wiltshire-Brodber, 1999: 137; Caldwell, 1999).

Stressing the importance of racial mixture provides the opportunity for people to pass as mixed. Although Anglo-Saxon phenotypical characteristics are preferred, Bocatoreneans do not emphasize their German or French ancestors to identify as white; rather, they identify as mixed, as Mestizos, or perhaps, as culisos. Traits that are more commonly associated with Anglo-Saxons (fair skin, straight hair, small nose and mouth, big eyes) are desired, yet a voluptuous body is considered beautiful, and for many men, a piel canela (cinnamon-colored skin). Bocatoreneans point out that Bocas is a clear example of a "melting pot," and by acknowledging this biological mixture, they point out that passing as white is simply not possible. Passing as mixed, however, is possible. Bocatorenean men and women bring attention whenever possible to the fact that their very dark grandfather from Martinique married their beautifully white Panamanian grandmother; or that their Indian mother was taken by the intelligence and hard working disposition of their Afro-Antillean father (Guerrón Montero, 2006a).

Other Bocatoreneans assert that finding a white woman with whom to have a relationship "is like winning the lottery" for two main reasons: because the "race is improved" if the couple ends up having children, and because the relationship guarantees a better economic life ${ }^{9}$. Some men would say that they just enjoy watching white tourists during their vacations. "Men love to watch white women. I think it's because of their skin color, their hair, because they like to wear bikinis and get tanned in the beach. In general, it is nice to see them" (interview C. R., May 8, 2002). Ramiro, an Afro-Antillean man who has a preference for white women, responded that Bocatorenean women are difficult women to please when it comes to courtship. If he tried to lure a Bocatorenean woman, she would ask him for food, drinks and presents, only to tell him later: "I don't want to be with you" or worse, to presume and comment to people: "I have
Ramiro wrapped around my finger. I got this and that out of him; how stupid of him!" White European and North American women are different. They go "straight to the point and don't play games." If a European or North American woman liked Ramiro, they would have an uncomplicated superficial relationship, or something more profound if they both wanted to.

John, a single Afro-Antillean man who is not interested in white women, believes that "people focus too much on the color of the skin, they don't care about love or about something special, a chemistry that develops, but only about the color" (interview J. S., July 24, 1999). For David, the economic resources of the white foreigners are less important than their skin color. If an Afro-Antillean man were to maintain a relationship with a mulatto or black foreigner, for instance, he would be criticized because he is "carrying wood to the forest," implying that in a place with so many black women, he chose a black foreign woman. Sydney Carrión, an Afro-Antillean for whom white women are beautiful, but who prefers AfroAntillean women as partners, noted that AfroAntillean men have more options than white Latino men in looking for a white female companion, because of the language barrier.

\begin{abstract}
We already have had experience with white Latina women; now white North American women are coming, and they are causing problems already! As you know, in Changuinola there are more Latinos. Here we have our Negroid race, our English language, and also Spanish. But men in Changuinola only speak Spanish, so because of communication, they are going to look for a white Latina. We can look for a white Latina but also for a white foreigner from North America or Europe because we speak English and can communicate with them too. In my opinion, the language has a lot to do with preferences (interview S. C., February 5, 2000).
\end{abstract}

Other men emphasize the fact that these women have more economic resources than them, and can provide them with the opportunity to enjoy amenities and commodities that are not easily accessible. César points out, "I think that everyone looks for better economic opportunities, so they try to find a tourist because it is very rare to see a poor tourist, a tourist without money or economic resources. Even if they don't invest on the island, if they are here they must have resources" (interview C. J., June 15, 2003).

\footnotetext{
${ }^{9}$ In fact, a popular Panamanian saying is "the money is where the gringo is" (Patiño 1997: 33).
} 
At the same time that white women provide status to men who interact with them, they also threaten their manhood because of their independence, more access to resources and willingness to pay for entertainment and other activities. As David Hurtado, a Mestizo man, said,

I think that many men don't want to have white women as partners not because they are not beautiful, but because we know how Black women have been raised. They are taught how to take care of themselves and their families. There are very few white women who have been taught how to cook and take care of the house. White women were taught how to survive outside the household, in society, because the white woman has always been over the black woman in society. Therefore, it was not expected that a white woman would marry a black man, because he would not give her the social status she deserved. So white women looked for men in higher levels, and in those levels, the women didn't need to learn how to take care of a house because there were black women available to take care of the house (interview D. H., May 2, 2000).

Itinerant tourists generate the same degree of fascination. Young adolescents on the island have made it a pastime to gather in groups and go to nearby beaches to observe tourists taking sunbaths topless. While John Stephenson, an older man from Bastimentos, disapproves of their behavior, he understands these men.

Here we are not used to seeing women in little bikinis; we have seen that only on TV. But there are even cases of tourists who swim naked. We are not used to these things; these people are more liberal that we are, they don't care about what others may say. Maybe in their countries there's nothing wrong with that, it's just a custom, but we are not used to that here (interview J. S., October 6, 2005).

Although there is a degree of solidarity among women, Bocatorenean women are also very protective of their husbands and families. Because of the fascination that is prevalent among men for white women, Bocatorenean women are particularly suspicious of white women without significant others. For AfroAntillean women, white women that are apparently available are first "the enemy," and they need to demonstrate their good intentions before being welcomed.

Sometimes, even if they try, they never are fully incorporated into society. Foreign women who are alone in Bocas are assumed by Bocatorenean men and women to be on vacation, accessible, and in need of a local companion (Pruitt and LaFont, 1995: 426). This situation clearly refers to Ang's (2001) observation that the moments of failure of communication among "different" feminist agendas, should not be encountered with dissatisfaction, but rather "should be accepted as the starting point for a more modest feminism, one which is predicated on the fundamental limits to the very idea of sisterhood (and thus the category 'women') and on the necessary partiality of the project of feminism as such" (Ang, 2001: 397; emphasis in the original text).

Conversely, many white women do hope to develop a relationship with an Afro-Antillean man. There is, as Meisch (1995) argues about the relationships between Otavalos and Euro-Americans in Ecuador, "mutual fascination with, romantic misconceptions of, and sometimes economic exploitation of the other gender" (1995: 441). In Bocas del Toro, "power in these relationships is shifting and situational, playing off traditional gender repertoires, as well as the immediate circumstances of finance and cultural capital" (Pruitt and LaFont, 1995: 422). In order to balance the uneven power dynamics, Afro-Antillean men and Euro-American women engage in manipulation and extension of their assumed gender repertoires (1995: 423). Afro-Antillean men in particular engage in public displays of manhood, in order to demonstrate their control in the relationship for Bocatoreneans are highly critical of relationships where the expected balance between men and women is challenged. Bocatorenean women who woo potential or actual lovers by paying for their entertainment are as criticized as foreign women who act similarly.

Less common are romantic relations between AfroAntillean women and white North American or European men. If the women develop steady family relationships with these men, and they stay in the Archipelago and provide for them or take them to their countries, people's commentaries are less negative. However, women who engage in romantic relationships with transient tourists are criticized, particularly if children result from the affairs. Men and women view their relationships with tourists or resident expatriates differently: while men look for white women for entertainment, women look for white men to find a possible long-term partner (Brennan, 2004). However, although the discourse of both men and women emphasizes the foreigner's 
economic status, education, or experience, as noted above, an essential component of the attraction found in a foreigner is their skin color, their whiteness, their straight hair and Anglo-Saxon facial features.

\section{Conclusions}

Barriteau establishes that "the ways in which masculinity and femininity are constructed reveal the gender ideologies operating in the state and in society. The statements of public officials, the bureaucratic and social practices of institutions, and representations of popular culture provide evidence of what is expected of, or appropriate for, the socially constituted beings, 'women' and 'men'” (1998: 191). Gender ideologies within a gender system demonstrate how individuals create gender identities. The personal constructions and social expectations of gender identities "form the core of gender ideologies within a particular society. These ideologies establish the sexually-differentiated, socially constructed boundaries for 'males' and 'females"” (Barriteau, 1998: 191).

In Bocas del Toro (and in large parts of Latin America), Euro-American women are assumed to be "liberal" and free persons, willing to take advantage of every opportunity to enjoy themselves. This perception is heightened by the fact that white women tourists come to Bocas del Toro on a vacation. Interestingly enough, and as Pruitt and LaFont clearly assert, these women are actually breaking the assumed gender scripts in their own cultures, by traveling alone, or by engaging in unsanctioned romantic relations.

\begin{abstract}
Many Euro-American women are seeking an identity beyond the confines of the traditional gender scripts offered in their cultures [. . .] With the ease and popularity offered by mass tourism, part of this negotiation is being conducted around the world as women travel independently from men. Free from their own society's constraints, female tourists have the opportunity to explore new gender behavior (1995: 423).
\end{abstract}

Cultural actions, or what Clifford calls "the making and remaking of identities," take place in the contact zones in Bocas del Toro, along "the policed and transgressive intercultural frontiers of nations, peoples, locales" (Clifford, 1997: 7).

Tourism and other globalizing phenomena need to be understood in the context of particular historical and spatially geographic circumstances. In the case of Bocas, tourism is not a one-way exchange. In an understanding of gazing and cultural consumption, tourists consume Afro-Antilleans as much as Afro-
Antilleans consume the tourists. As happens in every touristic borderzone, only the most superficial and evident elements of a given culture are represented and displayed for tourist consumption. In the case of Bocas del Toro, the elements that are on display and subject to change through tourism are ethnic commodities such as cuisine, music and dance, and handicrafts. More subtle elements like hybridization, less evident for tourists, are stressed out by AfroAntilleans during their interaction with them (Guerrón Montero, 2004, 2006b).

Are Afro-Antilleans engaged in a "sale of self"? To some extent, Afro-Antilleans are using dominant stereotypes about their "Caribbeanness:" careless lifestyle, tranquility, leisurely pace of life, virile and insatiable black men, beautiful and exuberant Black women, contrasting with innocent and asexual indigenous men and women. Particularly Afro-Antillean men working in tourism play what I call seduction games, carelessly flexing their muscles around female tourists, displaying their bodies and exaggerating their presence. Afro-Antilleans have dealt with commodification through accommodation. They live their negotiated identities of relaxed, contented people with very little to do except have fun, with hardworking women and lazy, handsome men forming muscles as they speak and dancing and singing for the tourists, or sharing a carefree, "traditional" lifestyle, of peacefully cohabitating with other ethnic groups, all the while exploiting them. The "ethnic identity" portrayed by Afro-Antilleans is one of creolization and hybridization. As Friedman (1994b) points out, "while virtually all cultures are plural and Creole in terms of the origins of their constituents, they neither appear nor are experienced as such unless they identify themselves as such" (1994b: 100).

These identities are partly produced by the Panamanian government, the media, resident expatriate groups, and a global image of the Caribbean, and partly produced by Afro-Antilleans and other ethnic groups. Bocas del Toro is portrayed by tourism mediators as a timeless, unmoved, unchanged area, where people have been engaging in the same activities for 
centuries, and where tourists' presence does not provoke any changes to this "off-the-beaten track" place. It could be argued that tourism is perceived by the national tourism authorities as a way to domesticate the "backward" Archipelago, composed of people with "backward" pasts, indigenous and black populations. The tourism industry brings them into "civilization," "from untamed nature into the realm of culture" (Bruner and Kirshenblatt-Gimblett, 1994: 456).

However, by maintaining, reinforcing, replacing, or marginalizing certain elements of their culture within the context of tourism, Afro-Antilleans develop a quiet rebellion against the Panamanian nation state, which tries to portray them in a simplistic manner, as the "authentic" Black populations of the country who have not changed their customs or traditions throughout generations. On the contrary, Afro-Antilleans want to present themselves as mixed, as the result of colonial and postcolonial interracial encounters, and as modern populations who still maintain some of their customs or traditions, for they deem them fundamental to their essence as Afro-Antilleans.

In the new climate of official tolerance that tourism has produced, Afro-Antilleans are exploiting their political/ethnic/racial ambiguity, in the making for decades, to reposition themselves in the context of the nation and the region. The recent tourism indus- try in Bocas has provided Afro-Antilleans with an opportunity to recreate a suppressed gendered, ethnic, and racial, identity represented in certain cultural traits, most noticeably in the areas of music and cuisine, which are markedly Caribbean.

Since their arrival in Bocas del Toro in the 1820s and in Panama City in the 1850s, Afro-Antilleans have been struggling to assert a distinctive cultural identity and at the same time to demonstrate their loyalty to Panama as their new land, for they see themselves not only as Afro-Antilleans, but as Panamanians. AfroAntilleans are attempting to enter the mainstream of Panamanian society on the basis of their unique heritage, a heritage that is both commoditized and reinvented for touristic purposes. They are asserting their difference as a subnational enclave. Tourism represents the latest "contact zone" in the history of the Archipelago. Wade reminds us that "a nationalist project does not just try to deny, suppress, or even simply channel an unruly diversity; it actively reconstructs it" (2000: 7). The representation of identities of Afro-Antilleans has been driven by local concerns as much as by a persistent awareness of a colonial past. Afro-Antillean agents are nowadays exploiting the ambiguity has characterized their history to relocate themselves with respect to current cultural politics in the Americas.

\section{Referencias}

- Anicetti, Denis 1998 “Infrastructure.” Destination Panama: 65-70.

- Barriteau, Eudine 1998 "Theorizing gender systems and the project of modernity in the twentieth-century Caribbean." Feminist Review 59: 186-210.

- Barrow, Christine

1998 "Introduction and overview: Caribbean gender ideologies," pp. xi-xxxviii in Christina Barrow (ed.), Caribbean portraits: Essays on gender ideologies and identities. Kingston: Ian Randle Publishers and The Centre for Gender and Development Studies.

- Brennan, Denise

2004 What's love lot to do with it?: Transnational desires and sex tourism in the Dominican Republic. Durham, NC: Duke University Press.

- Bruner, Edward and Barbara Kirshenblatt-Gimblett
1994 "Maasai on the lawn: tourist realism in East Africa." Cultural Anthropology 9(4): 435-470.

- Caldwell, Paulette M.

1999 "A hair Piece: perspectives on the intersection of race and gender," pp. 275-285 in Richard Delgado (ed.), Critical race theory: The cutting edge. Philadelphia: Temple University Press.

- Clifford, James

1992 “Traveling cultures,” pp. 96-112 in Lawrence Grossberg, Cary Nelson, and Paula A. Treichler, Cultural studies. New York: Routledge.

- Crain, Mary

1996 “Negotiating identities in Quito's cultural borderlands: native women's performances for the Ecuadorean tourist market,” pp. 125-137 in David Howes (ed.) Cross-cultural consumption: Global markets, local realities. London and New York: Routledge. 
- Friedman, Jonathan

1994 Cultural identity and global process. London, Thousand Oaks, CA and New Delhi: Sage Publications.

- Garcia Canclini, Nestor

1992 Culturas híbridas: Estrategias para entrar y salir de la modernidad. Buenos Aires: Editoral Sudamericana.

- Gillespie, Alex 2006 "Tourist photography and the reverse gaze." Ethos 34(3): 343-366.

- Guerrón-Montero, Carla

2002 "Like an alien in we own land:" International tourism, gender and identity in Afro-Antillean Panama. Unpublished PhD Dissertation, University of Oregon.

2004 "Afro-Antillean cuisine and global tourism." Food, Culture, and Society 7(2): 29-47.

2006a "Racial democracy and nationalism in Panama.” Ethnology 45(3): 209-228.

2006b "Tourism and Afro-Antillean identity in $\mathrm{Pa}$ nama." Journal of Tourism and Cultural Change 4(2): 65-84.

- Heckadon Moreno, Stanley

1992 “Sumario ejecutivo." Pp. 5-26 in Stanley Heckadon Moreno (ed.) Agenda ecológica y social para Bocas del Toro. Panamá: Impresora Continental.

- Henry, Paget

2000 "Caliban's reason: introducing AfroCaribbean philosophy.” Africana thought. London and New York: Routledge.

- Hollinshead, K

2004 'Symbolism in tourism: lessons from Bali 2002--Lessons from Australia's dead heart.” Tourism Analysis 8(2/4): 267-96.

- International Technical Cooperation Agreement (ITCA)

1993 Synthesis tourism development master plan for Panama 1993-2002. Panama: Panama Government Tourist Bureau IPAT and Organization of American States.

- Instituto Panameño de Turismo (IPAT) 2004 Análisis estadístico sobre el movimiento turístico-período enero a diciembre 2002-2003. Panamá: Instituto Panameño de Turismo.

- Johnson Osirim, Mary
1997 "We toil all the livelong day: women in the English-speaking Caribbean,” pp. 41-67 in Consuelo Lopez-Springfield (ed.) Daughters of Caliban: Caribbean women in the twentieth century. Bloomington and Indianapolis, Indiana, and London: Indiana University Press and Latin America Bureau.

- Kirshenblatt-Gimblett, Barbara and Edward Bruner 1992 “Tourism,” pp. 300-307 in Richard Bauman (ed.) Folklore, cultural performances, and popular entertainments: A communications-centered handbook. New York and Oxford: Oxford University Press.

- Maynard, Mary

2001 “'Race,' gender and the concept of 'difference' in feminist thought,” pp. 121-133 in Kum Kum Bhavnani (ed.) Feminism and 'race,' Oxford Readings on Feminism. Oxford: Oxford University Press.

- Meisch, Lynn

1995 "Gringas and otavaleños: changing tourist relations." Annals of Tourism Research 22: 441462.

- McIntosh, Robert Woodrow, Charles R. Goeldner, and J. R. Brent Ritchie

1999 Tourism: principles, practices, philosophies. 8th edition. New York: Wiley.

- Mohammed, Patricia

1998 "Editorial: rethinking Caribbean difference." Feminist Review 59: 1-4.

- O’ Connell Davidson, Julia

1998 Prostitution, power and freedom. Cambridge: Polity.

2002 "The rights and wrongs of prostitution." Hypatia 17(2): 84-98. Feminist Philosophies of Love and Work (Spring, 2002).

- Opperman, Martin (ed.)

1998 Sex tourism and prostitution: Aspects of leisure, recreation, and work. New York: Cognizant Communication.

- Patai, Daphne

1991. "U.S. academics and third world women: is ethical research possible?," pp. 137-153 in Shema Berger Gluck and Daphne Patai (eds.) Women's words: The feminist practice of oral history. New York: Routledge.

- Patiño, Arnulfo

1997 "Xenofilia, pecado capital de la sociedad panameña.” Revista Cultural Lotería 415: 29-39. 
- Paulson, Susan

2007 "Modern norms, queer fields of study, and emerging social movements in Bolivia.” Paper presented at the XXVII International Congress of the Latin American Studies Association. September 58, 2007. Montréal, Canada.

- Pritchard, Annette and Nigel Morgan

2005 'On location': Re(viewing) bodies of fashion and places of desire." Tourist Studies 5(3): 283302.

- Pruitt, Deborah and Suzanne Lafonte

1995 "For love and money: romance tourism in Jamaica.” Annals of Tourism Research 22(2): 422440 .

- Sánchez Taylor, Jacqueline

2001 "Dollars are a girl's best friend? Female tourists" sexual behaviour in the Caribbean." Sociology 35(3): 749-64.

- Segal, Lynne
1999 Review of Prostitution, power, and freedom, by Julia O' Connell Davidson. The American Journal of Sociology 105(3): 874-876.

- Shepherd, Catherine

1999 "Introduction," pp. xvi-xviii in Patricia Mohammed and Catherine Shepherd (eds.) Gender in Caribbean development, Second edition. Kingston: Canoe Press University of the West Indies.

- Veijola, Soile and Eeva Jokinen. 1994 "The body in tourism." Theory, Culture and Society 11(3): 125-151.

- Wade, Peter 2000 Music, race, and nation: Música tropical in Colombia. Chicago and London: The University of Chicago Press.

- Wiltshire-Brodber, Rosina

1999 "Gender, Race and Class in the Caribbean," pp. 136-148 in Patricia Mohammed and Catherine Shepherd (eds.) Gender in Caribbean development, Second edition. Kingston: Canoe Press University of the West Indies.

\section{Forma de Citación}

GUERRÓN MONTERO, Carla: Black is not as beautiful: gender, sexuality and tourism in Panama. Revista Communication Papers, $N^{0} 1$, páginas 17 a 28. Departamento de Filología y Comunicación de la Universidad de Girona. Recuperado el _ de_ de 2 de: http://www.communicationpapers.es 
